Article

\title{
Remote Sensing Materials for a Preliminary Archaeological Evaluation of the Giove Countryside (Terni, Italy)
}

\author{
Pier Matteo Barone*(D), Elizabeth Wueste and Richard Hodges \\ American University of Rome, Archaeology and Classics Program, Via P. Roselli 4, 00153 Rome, Italy; \\ e.wueste@aur.edu (E.W.); r.hodges@aur.edu (R.H.) \\ * Correspondence: p.barone@aur.edu
}

Received: 3 June 2020; Accepted: 22 June 2020; Published: 24 June 2020

check for updates

\begin{abstract}
A collaboration between the American University of Rome, the Municipality of Giove, and Soprintendenza Archeologia, Belle Arti e Paesaggio dell'Umbria has resulted in an academic project aimed at a preliminary evaluation of a particular area along the Tiber river that straddles the border between Umbria and Lazio. Archaeological prospection methods, such as Unmanned Aerial Vehicle (UAV)-based remote sensing, ground-penetrating radar (GPR), and photogrammetry, have made it possible to better study the landscape with respect to not only the changes the area has undergone recently, but also its evolution during the Roman and Medieval periods, while keeping the main communication route represented by the Tiber river as its fulcrum.
\end{abstract}

Keywords: GPR; drone; photogrammetry; archaeological prospections; survey; landscape archaeology; Tiber river; Italy

\section{Introduction}

Non-invasive methods in archaeology have been widely used with successful results for many years [1-4]. In particular, photogrammetry [5,6], drone-borne imagery [1,7], and ground-penetrating radar (GPR) [8-12] have yielded very encouraging results from both a methodological and archaeological point of view. The use of these methodologies is also fundamental to better understanding the historical evolution of specific sites during specific periods $[4,13]$. For this project, we studied the territory of Giove, focusing in particular on areas close to the Tiber river.

The Tiber is the most significant river in Central Italy. It flows some 400 kilometers through a long valley, starting from the Emilia-Romagna region, through Tuscany, Umbria, and Latium (and Rome), and finally to the Tyrrhenian Sea in Ostia. The river has had positive as well as negative effects upon the growth of Rome (e.g., floods). Compared to other transportation methods, it offered an affordable and cost-effective manner of sending goods to the city by water. Because the river Tiber went as far as the city, it allowed Rome to develop at a safe distance from the Tyrrhenian Sea, providing security against naval fire or invasion $[14,15]$.

The Tiber valley is a tectonic depression formation that is primarily filled with alluvial deposits of sand and clay, which have formed a horizon of low hills that are easily subject to erosion [16]. This landscape has determined settlement strategies since prehistoric times, with people favoring the more solid soils for housing and reserving the less cohesive ones for agriculture. In addition, it has remained quite attractive throughout the ages due to the course of the Tiber river, especially the left bank (geomorphologically the most stable), which offered settler communities many opportunities for connection, defense, and trade $[16,17]$.

Throughout the centuries, the relevant parts related to the river's navigability have created the possibility of multiple harbors along its course throughout Central Italy [17]. One such area was 
investigated in this study, with a particular focus on the ancient Roman Republic (2nd-1st century BCE) and early Medieval (10th-12th century CE) periods. The countryside of the current Comune di Giove (within the Umbria region, but close to the boundary of the Latium region) has brought to light several archaeological discoveries that have allowed us to better understand its landscape evolution, particularly during the Roman period [17-28].

Based upon previous interesting archaeological surveys done in the area $[27,29,30]$, this non-destructive technique (NDT) research project was focused on two main areas above the Tiber river: (i) San Valentino and (ii) Malvicino (Figure 1). The purpose of this work was both academic and methodological. On the one hand, the involvement of students allowed us to teach them the best practices for the use of remote sensors in an archaeological context; on the other hand, the support of the local bureau for archaeology (the Soprintendenza Archeologia, Belle Arti e Paesaggio dell'Umbria) allowed us to better understand the fragmented information related to the historical Giove landscape.
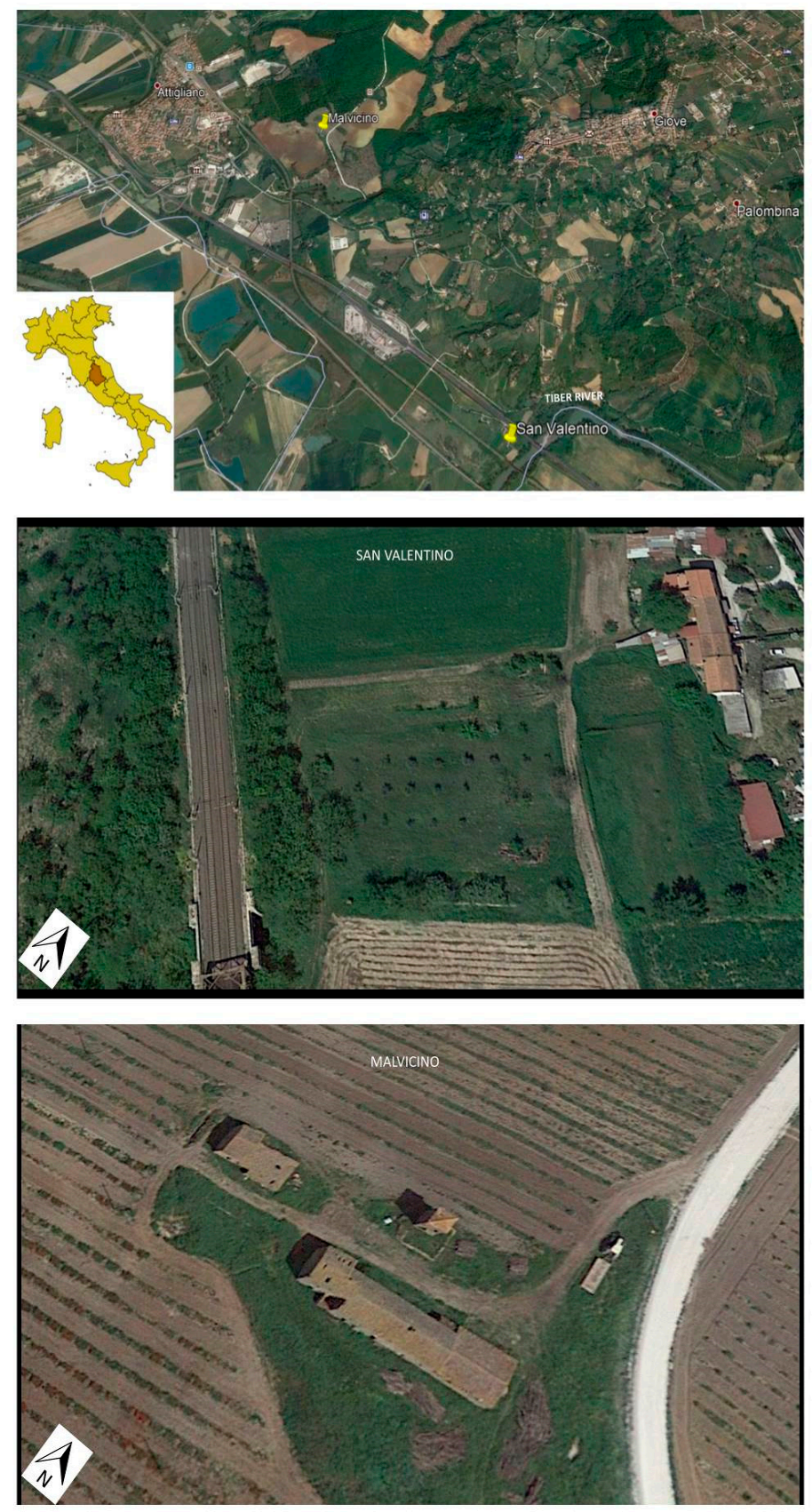

Figure 1. The general location of the two sites (above) and their detailed locations (below). 


\subsection{San Valentino}

The first site examined was San Valentino, located just north-west of a bend in the Tiber river on private farmland. The most visible monument here is a long wall (about $30 \mathrm{~m}$ long $\times 2.5 \mathrm{~m}$ high). The core of the wall is made of opus caementicium (ancient Roman concrete), and its south-east face is made of small irregular limestone blocks, most of which have an exposed face and a rectangular shape with a distinctive herringbone coursing (or opus reticulatum) that is punctured by a series of doors and windows faced with Roman bricks. It is oriented almost parallel to the Tiber river (Figure 2a,b) [17,18,28-31].
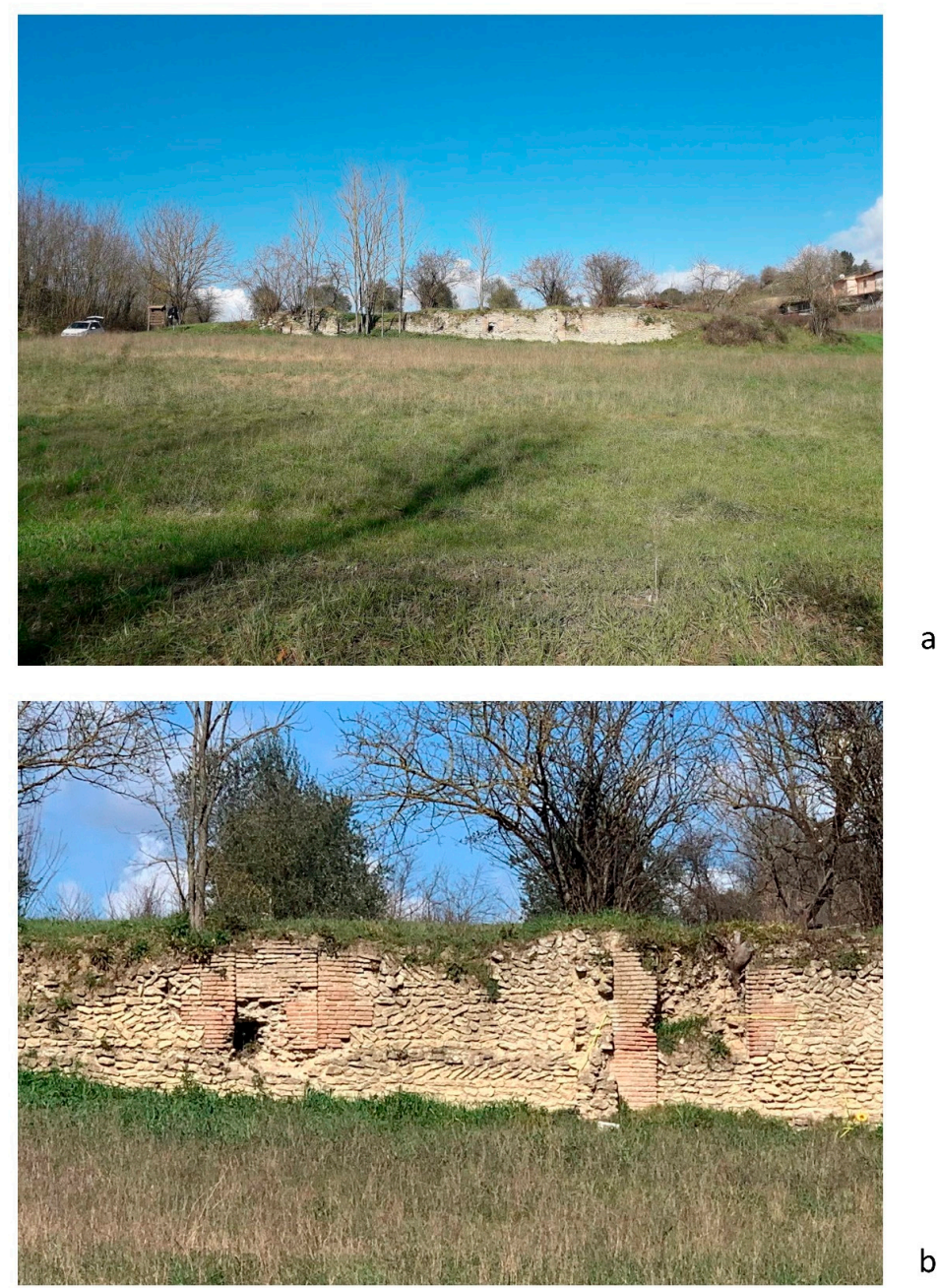

Figure 2. (a) The remains of the south-facing ancient wall lining the olive grove. (b) A detailed view of the coursing.

This wall defines the south-east side of a modern olive grove and some lightly ploughed fields. These fields produced ancient bricks, tiles, coins, well-preserved mosaic tesserae, and ceramics during the late Republican and early Imperial periods [27,28]. A few fragments are still easily visible to the naked eye. As it is located near the left bank of the Tiber river, it is likely to have been part of a riverside settlement [17-19,21,22,24,25,27,28,30-32]. Moreover, previous archaeological surveys have found kilns nearby, which could have produced materials for Rome's rapid expansion in the late Republican and early Imperial periods [27].

After the Roman period, this wall apparently once terminated at a 9th or 10th century CE church known as San Valentino. During the construction of the 19th-century Rome-Florence railway, the ruins of this church were destroyed by the left shoulder of the bridge by which the railroad crossed the river 
Tiber. Some decorated stones that were recovered by the then-current inhabitants were walled into the face of the current farm and are still visible today [18,28,29].

Finally, between the farmhouse and the public road to the east, multiple inhumed bodies have been found. These must have been part of the burial ground that extended further east since the opening of the A1 motorway (called Autostrada del Sole), as an a cappuccina necropolis (tile-tent tomb) was found nearby $[18,28]$.

\subsection{Malvicino}

The second site, Malvicino, was an abandoned modern farm with a pigsty on the top terrace of a hill that overlooks both the east side of the Tiber river as well as the Pleistocene lava dome complex near the town of Viterbo (north of Rome) [33]. Behind the pigsty, two large masonry blocks form part of a large monument on a well-made terrace (Figure 3a). A modern electrical tower sits on a small platform made of ancient Roman opus caementicium (Figure 3b). A large fragment of a late-Republican Dressel 1 amphora is embedded in the wall of the farmhouse. Further clues about the age of this potentially ancient monument are the decorative composite squares of Roman floor tiles, broken up and dispersed among the walls of the most recent (late 19th century) buildings, several fragments of ancient tiles, and the remains of a retaining wall or partially preserved cistern (Figure 3c) $[18,34]$.
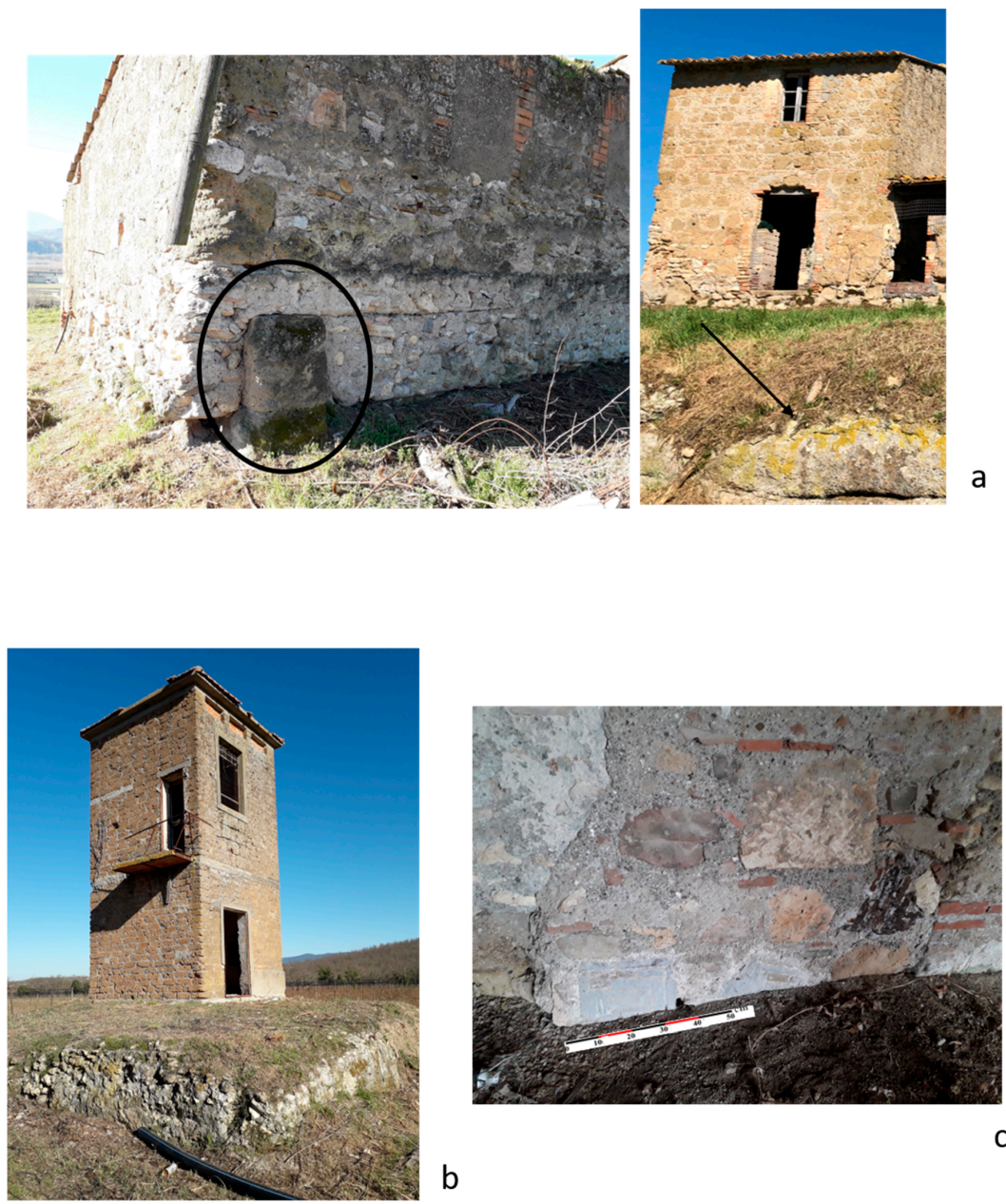

b

Figure 3. The site of Malvicino, including modern constructions. (a) The pigsty with probable ancient masonry blocks still in situ (circled in black) and the remains of the retaining wall or partially preserved cistern (indicated by the black arrow). (b) The electrical tower standing on top of a platform that is partially constructed of opus caementicium. (c) Ancient Roman fragments reused to decorate the walls of the modern farmhouse. 


\section{Materials and Methods}

Both of these areas were surveyed using different remote sensing (RS) techniques. First, a DJI Mavic Mini drone was used to collect aerial photos, not only to detect possible parch marks on the surface, but also to better understand the general disposition of the still-visible remains in relation to the areas under investigation.

The second RS method used was the GPR. Specifically, a Noggin ${ }^{\circledR}$ SmartCart ${ }^{\circledR}$ (Sensors \& Software, Inc.) with $500 \mathrm{MHz}$ antennas was employed. A series of Y-grids were collected in both areas with similar parameters due to the similarities in the soil and dielectric constant conditions $(0.5 \mathrm{~m}$ interline; Stacking 4; v = $0.90 \mathrm{~m} / \mathrm{ns}$ using the hyperbola calibration; setting of the zero-time position relative to the ground surface). The data were of good quality, but images were set to "amplify" the strength of the GPR data signals in both the GPR lines and depth slices. In particular, for both areas, a combination of dewow, migration, envelope (DME), background subtraction, and user gain (start gain between 0.5 and 3, attenuation between 1 and 3, and maximum between 500 and 1000) were used. The attenuation value defined the steepness of the gain function. Lower values resulted in a more gradual slope, while higher values produced steeper slopes. The value slope began at the start gain value and increased until the maximum gain value (the highest multiplication factor that can be applied to GPR line data) was reached. Together with the GPR, a commercial metal detector (Garrett Euro Ace ${ }^{\circledR}$ ) was used to check for any metallic objects near the surface. As mentioned above, the area has been particularly disturbed by ploughing throughout this century. Because of this, the purpose of using the metal detector was not to detect archaeological metal findings, but rather to remove metal objects that might disturb the GPR.

Finally, in some buildings, a series of photos were collected for a 3D reconstruction of the two most relevant structures in San Valentino and Malvicino. In particular, photogrammetry was performed for the ancient wall in San Valentino and for the internal walls of the pigsty in Malvicino, using the free software 3DF Zephyr $3 \mathrm{D}^{\circledR}$ with parallel axis capture [6,35].

\section{Preliminary Results}

\subsection{Drone-Borne Imagery}

\subsubsection{San Valentino}

The fieldwork included the use of a drone to not only observe the presence of parch marks from above, but also to map the dispersions of ancient potsherds, tiles, and other materials, and to establish the best possible conditions for geophysical prospecting (Figure 4). The drone was also useful in obtaining a better understanding of the general orientation of the wall, as mentioned above, in relation to the Tiber river (Figure 4a). Even though the reddish sherds were already visible to the naked eye, the drone confirmed their dispersion throughout the field, as they had changed the color of the superficial soil from brown to reddish (Figure 4e). However, no particular parch marks were noticed except at some sporadic points (Figures 4 b and 5), which were later investigated by geophysical prospections.

\subsubsection{Malvicino}

As for the San Valentino area, the drone-borne images were useful in better understanding the layout of the modern farm (and especially of the pigsty) in relation to the containment wall/cistern mentioned above (Figure $4 \mathrm{~d}$ ), as well as in consideration of the subsequent geophysical investigations. No particular processing or elaborations were carried out. Moreover, the drone-borne images confirmed that the 20th-century electrical tower was isolated on a partially preserved Roman opus caementicium base (Figure 4c), with the surrounding pozzolana (the local bedrock) having been removed for the construction of the adjacent A1 motorway [36,37]. 

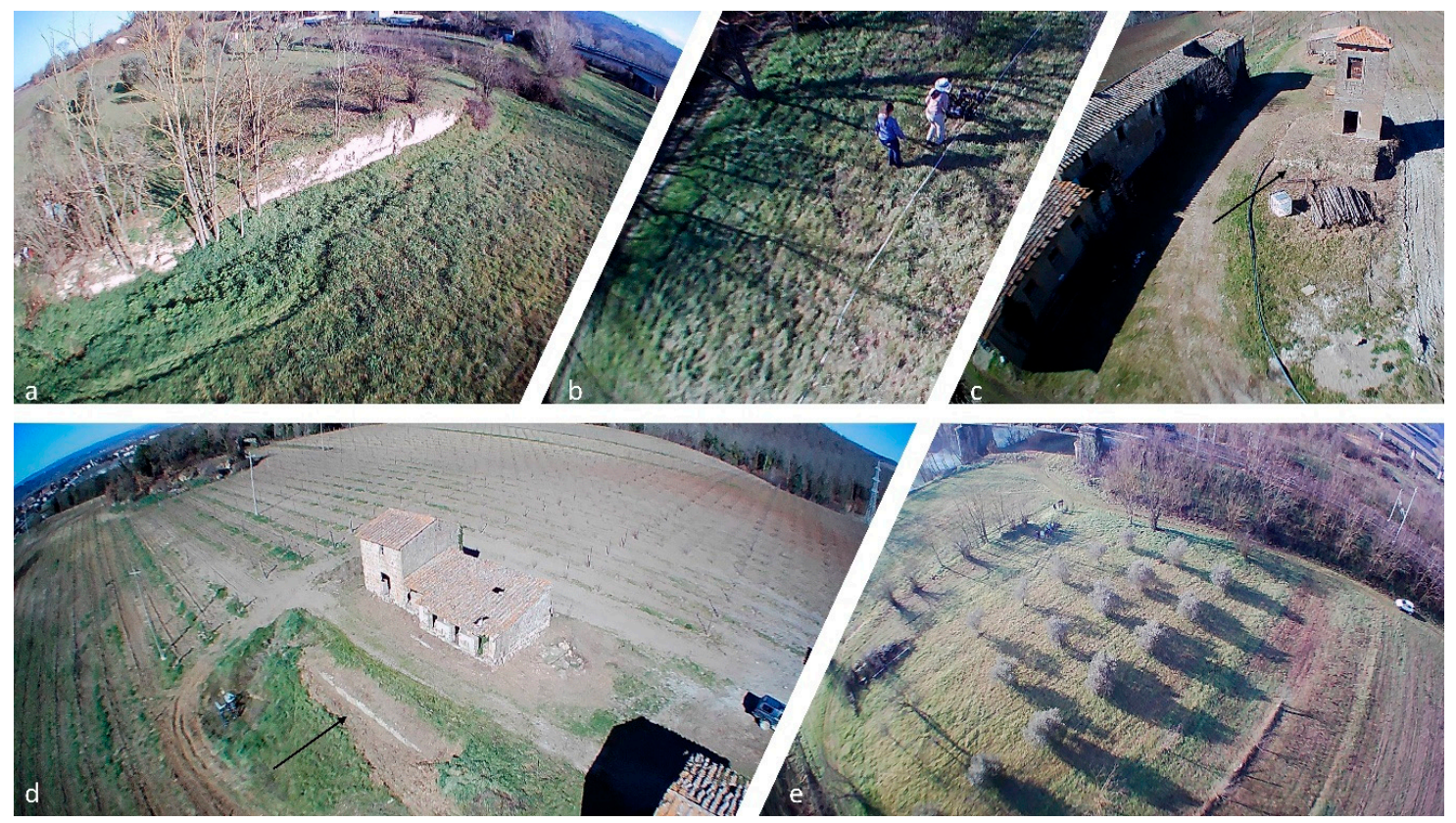

Figure 4. Drone-borne imagery. (a) The wall and the olive grove (San Valentino). (b) The parch marks on which the grass is less green (San Valentino). (c) The opus caementicium foundation of the electrical tower can be seen (Malvicino). (d) The retaining wall/cistern in front of the pigsty (Malvicino). (e) On the right side, the dispersion of the ancient sherds can be seen, which are particularly visible due to the reddish color of the superficial soil (San Valentino).

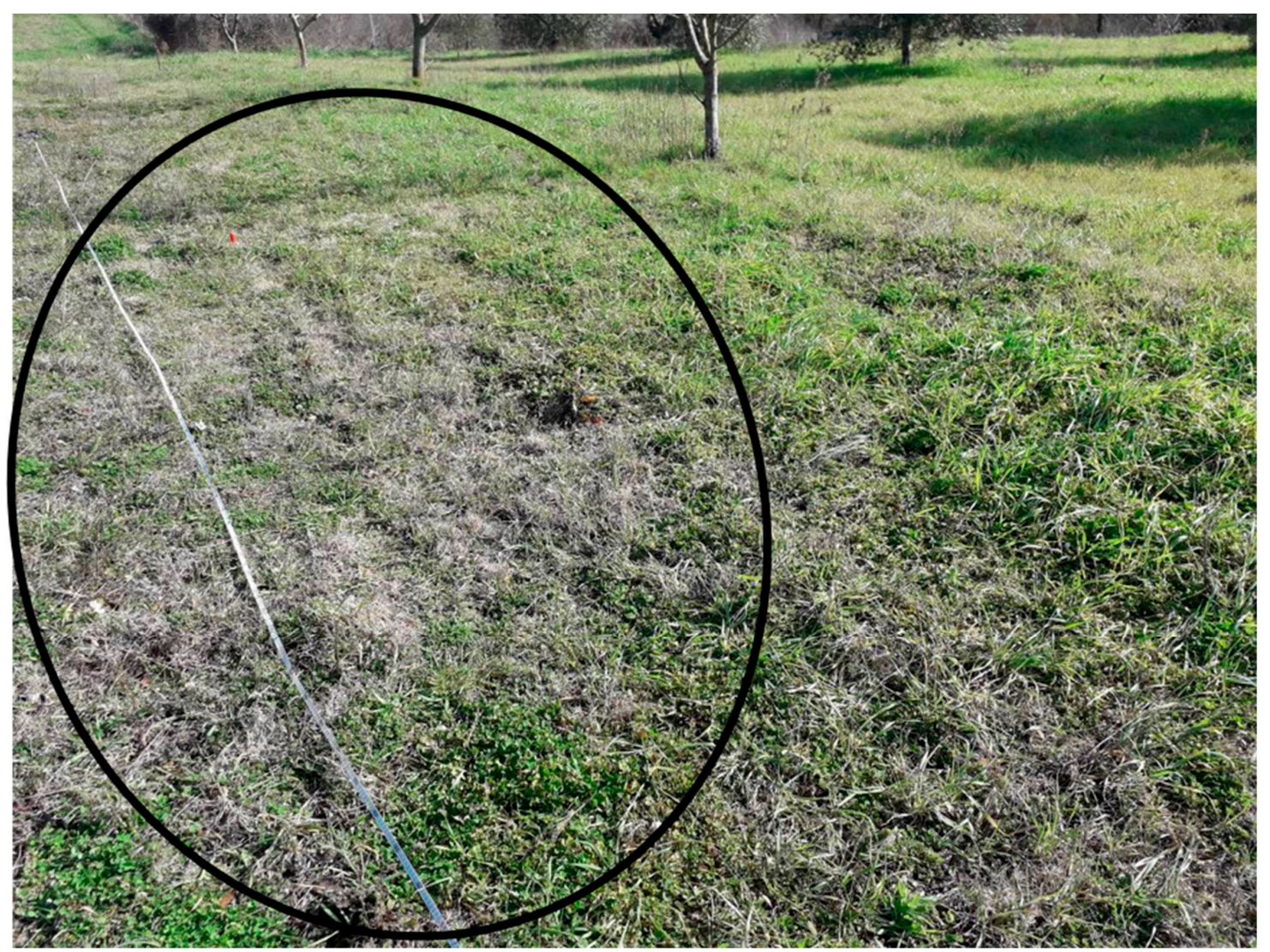

Figure 5. The visible parch marks with grass that is a paler green due to possible buried manmade structures. 


\subsection{Geophysical Prospections}

\subsubsection{San Valentino}

The surface of the ground was initially probed using a metal detector to detect ancient objects and, above all, to eliminate the areas where modern metal elements could disturb the subsequent passage of the GPR. The only result was a fragment of shrapnel, probably from a World War II bomb; this area was heavily bombed during WWII due to the presence of the railway [38].

Figures 6-8 illustrate the 30-40 $\mathrm{m}$ Y-oriented grid in the SE-NW direction, at different depth slices from $0.2 \mathrm{~m}$ to $1.5 \mathrm{~m}$, and their corresponding radargrams. In particular, at a depth of about $0.2 \mathrm{~m}$, we noticed the presence of an anomaly along the baseline, parallel to the partial remains of the wall. This anomaly, considering its shallowness, geometry, and orientation, could be related to the wall in question-perhaps a northward extension of a related harbor building or storeroom (Figure 6). It is interesting to note how, at a depth of $1 \mathrm{~m}$, there were perpendicular and linear anomalies that suggest buried wall structures. These anomalies are orientated towards the railway tracks in the western half of the map (Figure 7). Moreover, they correspond to the parch marks on the surface previously illustrated in Figure 5.

Finally, at a depth of $1.5 \mathrm{~m}$, we noticed a geometric anomaly circumscribed in the western area (Figure 8). Figure 9 shows the pseudo-3D reconstruction of the anomalies identified at a depth of about $1 \mathrm{~m}$, highlighting their course and very particular geometry, probably anthropic in nature.

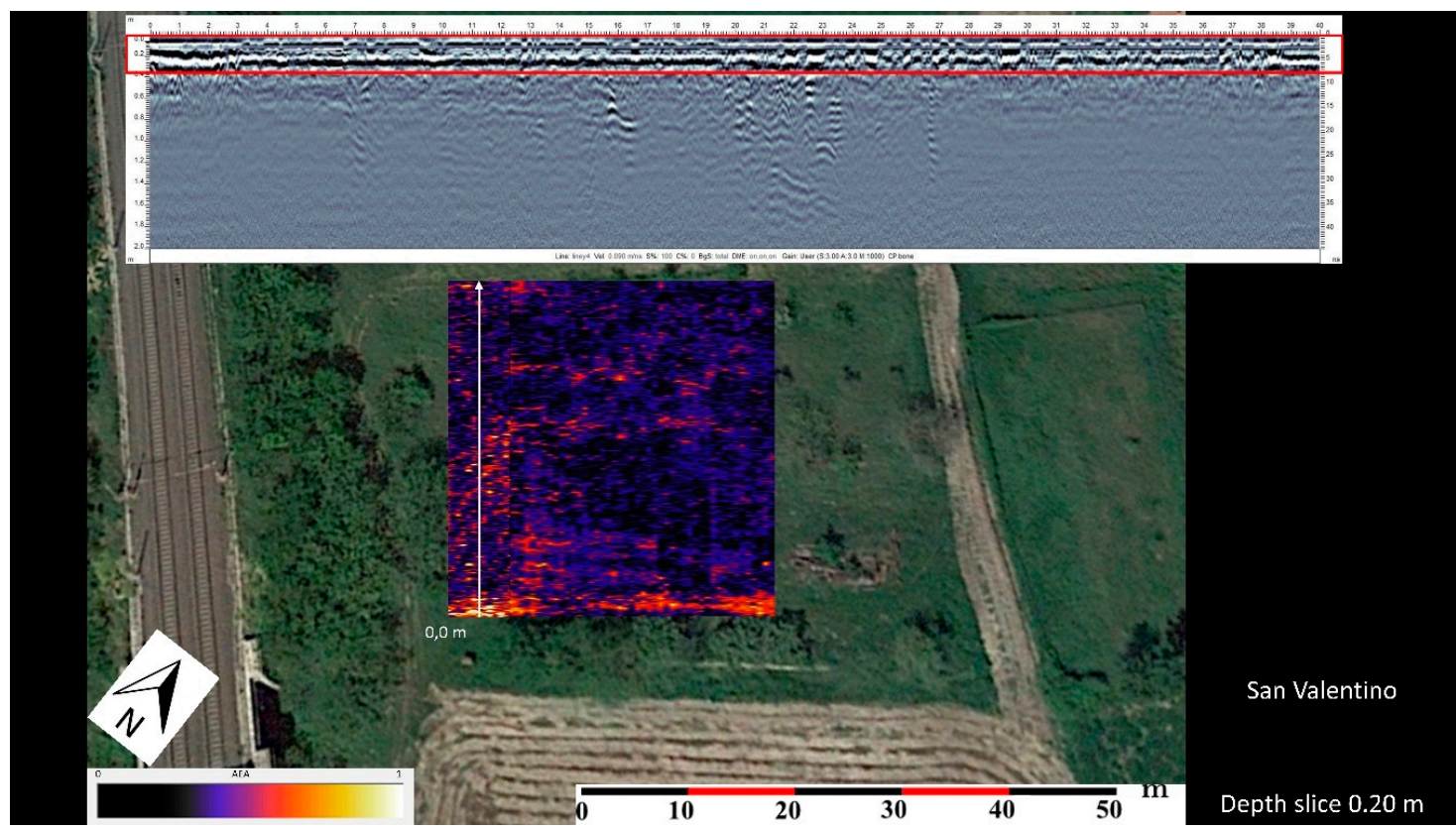

Figure 6. The ground-penetrating radar (GPR) map at $0.2 \mathrm{~m}$ depth, in which the anomaly parallel to the visible wall can be seen. Above is the radargram collected along the white arrow, with a red rectangle indicating the relative depth of the map. 


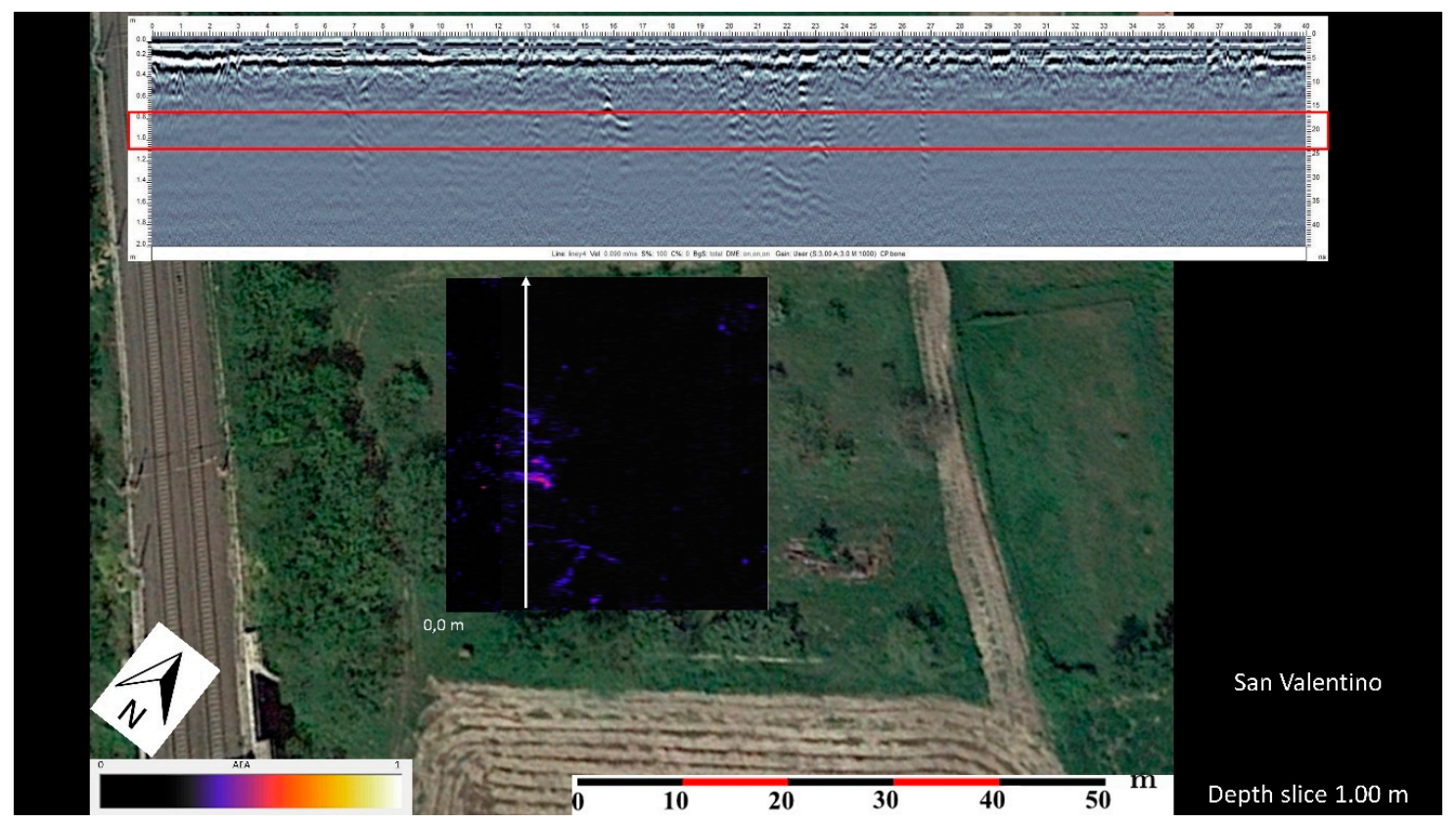

Figure 7. The GPR map at $1 \mathrm{~m}$ depth, in which several perpendicular and linear anomalies, probably due to manmade walls, are visible. Note that there are parch marks on the surface that correspond to these anomalies. Above is the radargram collected along the white arrow, with a red rectangle indicating the relative depth of the map.

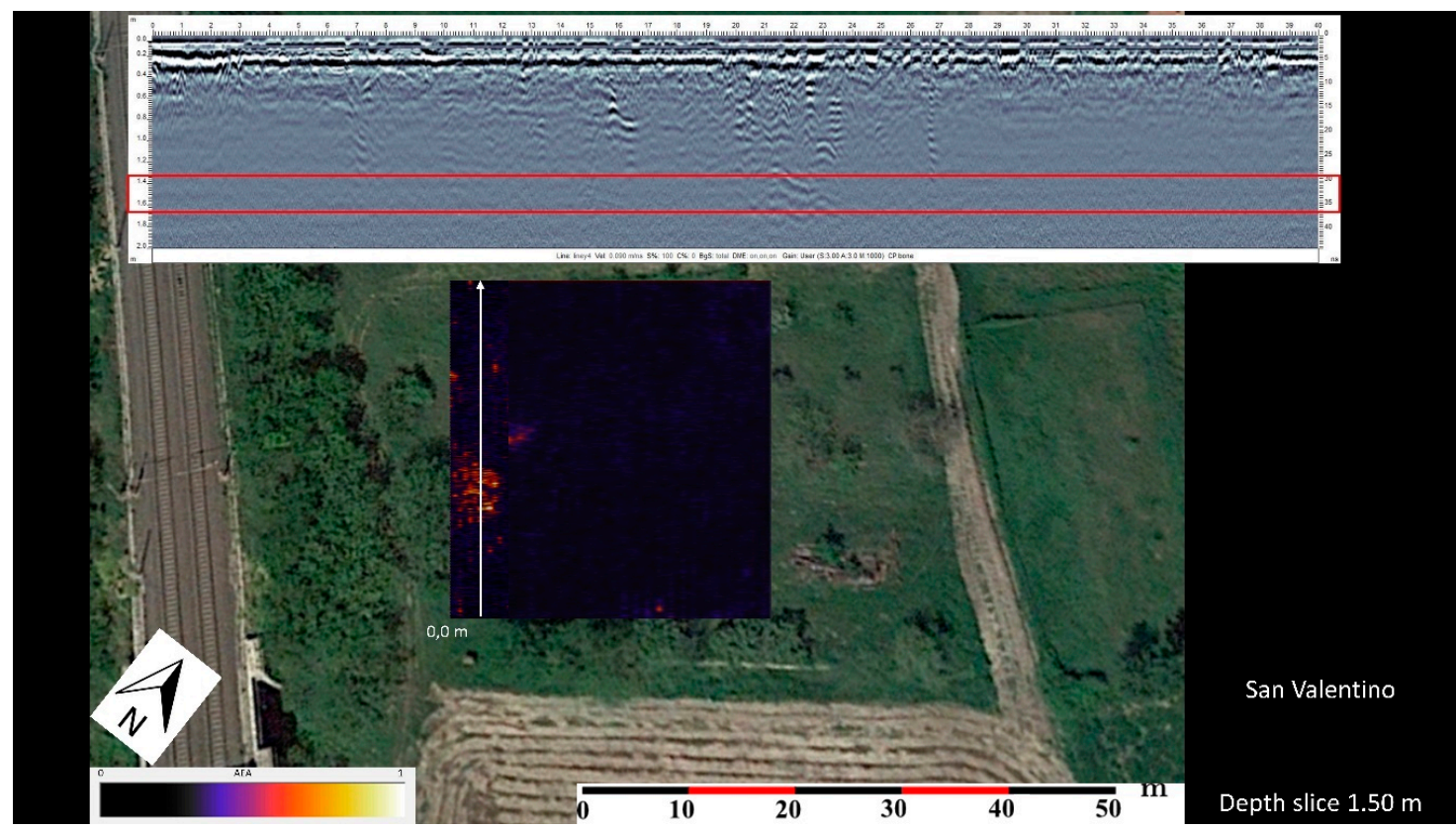

Figure 8. The GPR map at $1.5 \mathrm{~m}$ depth, in which a circular anomaly concentrated along the side of the railway tracks is visible. Above is the radargram collected along the white arrow, with a red rectangle indicating the relative depth of the map. 


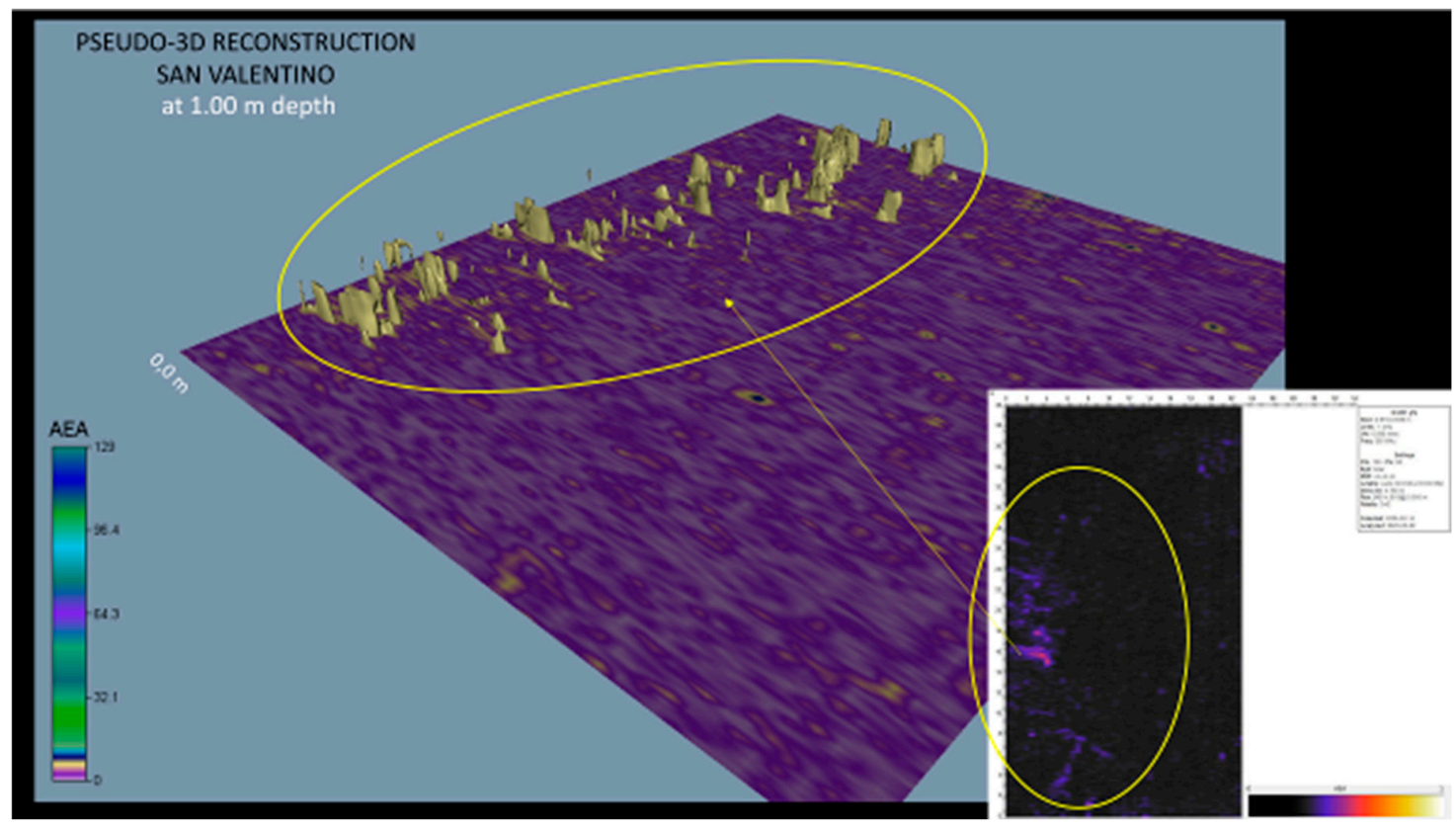

Figure 9. The pseudo-3D reconstruction of the anomalies identified by the linked map (bottom right) at a depth of up to $1 \mathrm{~m}$.

\subsubsection{Malvicino}

In this area, the GPR was concentrated on collecting information about the subsoil between the various modern structures (i.e., the farm, tower, and pigsty) and the possible containment wall/cistern positioned in front of the pigsty.

Figure 10 illustrates the two largest grids (in the E-W and S-N directions, respectively) and two smaller grids around the tower and on top of the basement (in the W-E and S-N directions, respectively), all of them at two different depth slices $(0.3 \mathrm{~m}$ and $0.6 \mathrm{~m})$, and their corresponding radargrams. These maps show evident subsurface anomalies. Some of them seem to be related to modern structures, such as modern foundations; others look elongated and are probably related to modern pipelines. However, there is nothing in the GPR data to suggest a connection with previous ancient buildings or to explain the presence of ancient decorative elements and the containment wall/cistern. 


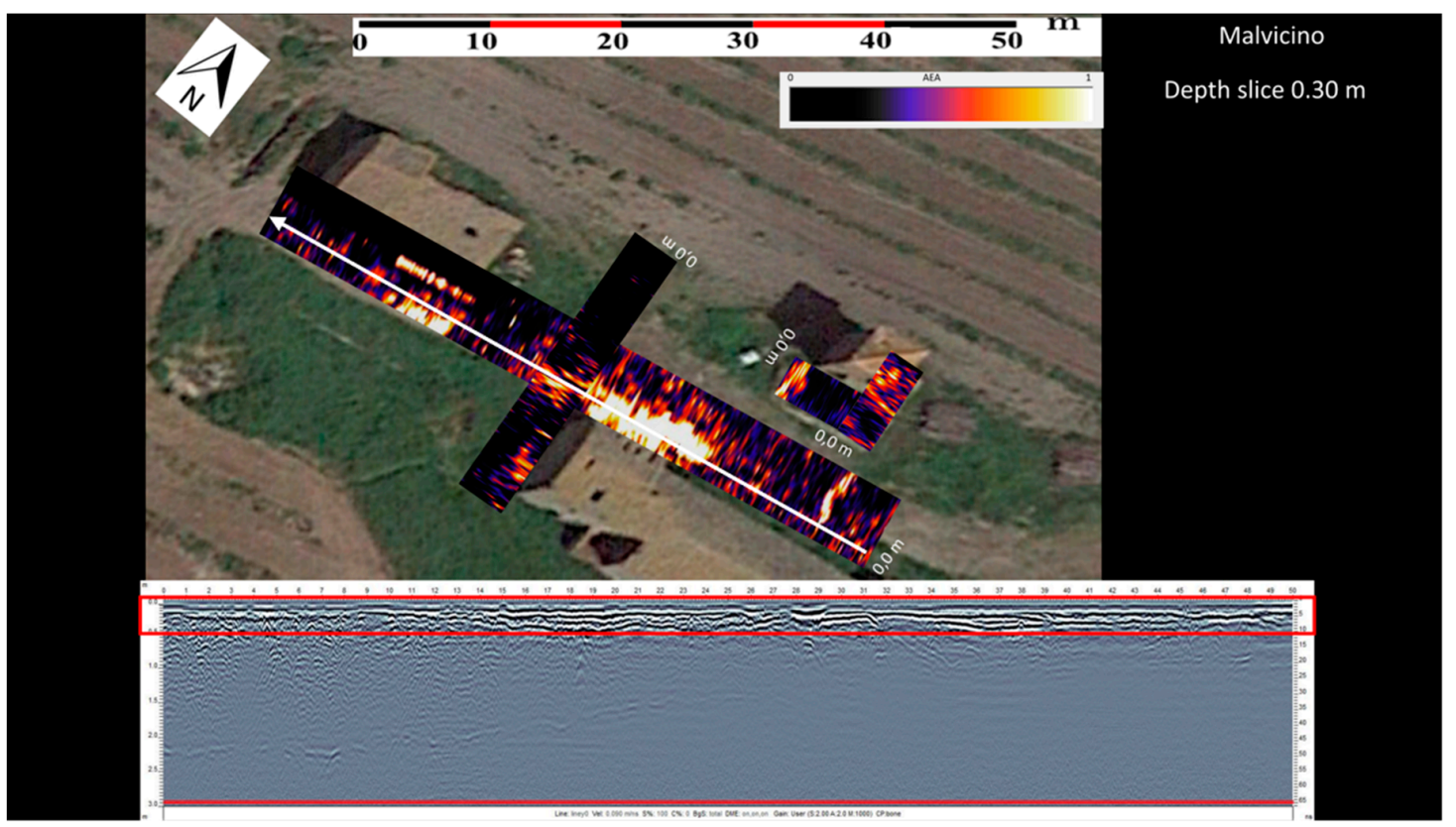

a

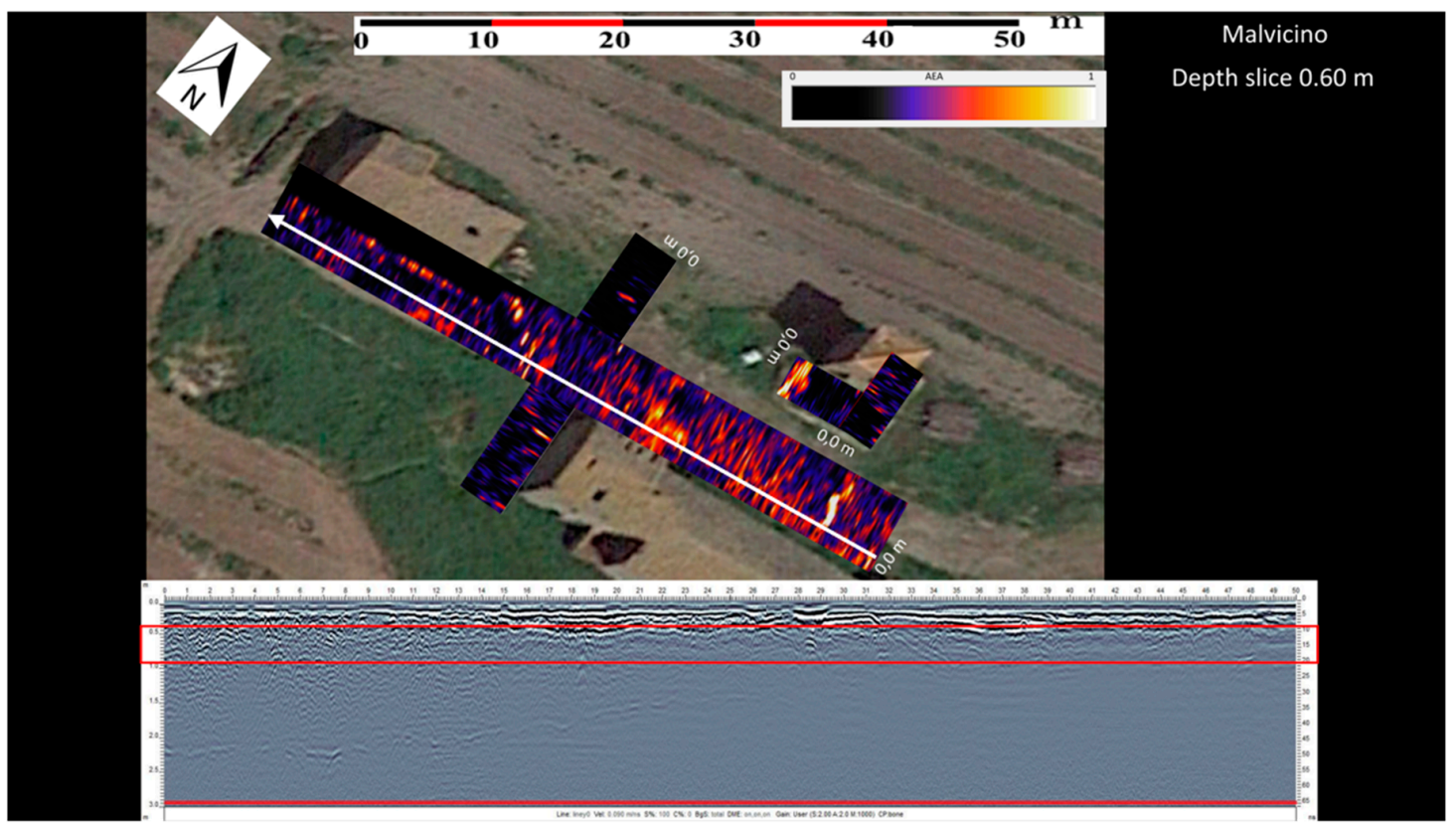

Figure 10. (a) The GPR map at a depth of $0.3 \mathrm{~m}$. (b) The GPR map at a depth of $0.6 \mathrm{~m}$. The anomalies potentially related to the modern structures are visible. Below are the radargrams collected along the white arrows, with red rectangles due to the relative depth of the map.

\subsection{Photogrammetry}

\subsubsection{San Valentino}

The photogrammetric work performed in this area involved the collection of a series of photographs of the wall from different angles and their photogrammetric reconstructions to generate a 3D mesh from the point clouds. The result is shown in Figure 11a, which depicts mesh filtering with photo-consistency 
and the 3D restitution of the wall. This allowed for the accurate reconstruction and quick documentation of the wall to be included in the final database, as legally requested by the Soprintendenza and the Italian Central Institute of Archaeology (Istituto Centrale per l'Archeologia-ICA).
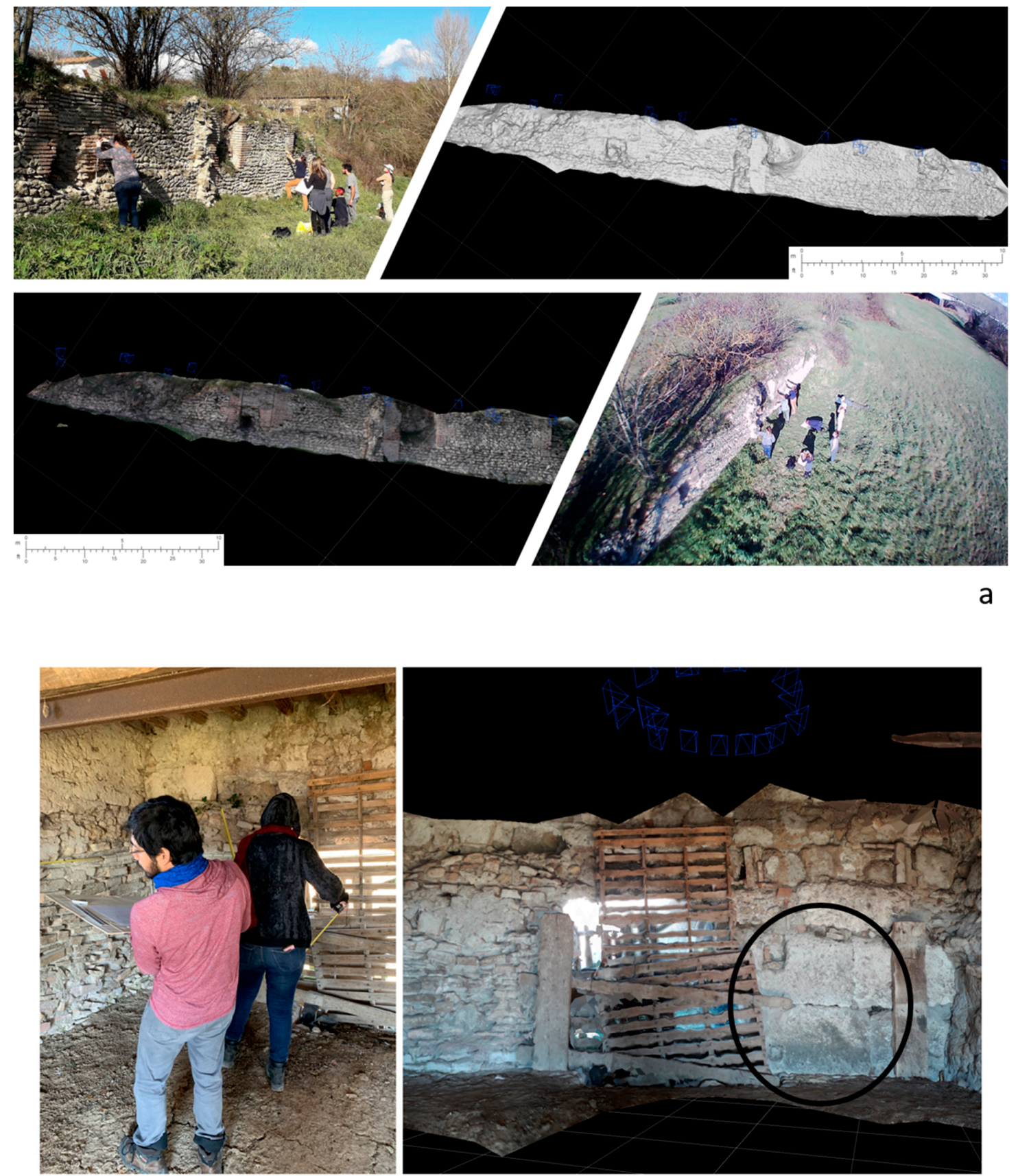

b

Figure 11. (a) The two 3D reconstructions based on the photogrammetry of the ancient wall in San Valentino. (b) An internal view of the pigsty with the two in situ masonry blocks on the bottom right.

\subsubsection{Malvicino}

A similar photogrammetric survey was also carried out in this area. However, at this site, the structure of the pigsty's interior (versus exterior) was processed to accurately document the reuse 
of ancient blocks and various other elements. Figure $11 \mathrm{~b}$ shows the result of the $3 \mathrm{D}$ reconstruction, with two large reused blocks in the lower-right corner. They appear to still be in situ (i.e., these blocks have not been moved from their original structural positions).

\section{Discussion and Conclusions}

Due to the two main above-mentioned aims of this project, academically speaking, the Giove countryside is an ideal area in which to explain and perform different RS methods for students. Based on this RS survey, it is possible to attempt a preliminary contextual interpretation of the documented evidence. It is likely that the San Valentino site was a port along the Tiber river, consistent with similar sites to the north and south, and also consistent with the previously mentioned sources. The evidence described above, in addition to the anomalies found by the GPR, could refer to a settlement, dating back from between the Republican and Imperial periods, which, at least in Roman times, in addition to having residential characteristics, was likely connected to a river harbor. The existence of the harbor was also suggested by its proximity to a production site, suggested by the visible ceramic material, intended to supply goods to Roman markets via the Tiber river [27]. The area was occupied, perhaps without interruption, until the early Middle Ages, during which time a religious building was constructed, and whose above-described stone elements, chronologically located between the 9th and 10th centuries, document either the original construction phase or a later renovation [28].

With regard to the Malvicino site, however, the investigations did not lead to substantial hypotheses. The presence of reused ancient materials in the modern structures of the farm and pigsty (e.g., tiles and amphora fragments) did not particularly match any of the geophysical results. The in situ presence of the two large corner blocks, which were subsequently used to build the modern pigsty, and also highlighted by photogrammetry, may suggest the presence of a small structure, perhaps a small hilltop temple, due to both its orientation and the use of monumental rectilinear stones, along an ancient Roman route from northern Lazio to central Italian towns like Amelia [20]. Furthermore, it was not possible to clearly resolve the issue of the structure visible to the south of the pigsty. There seems to be no geophysical evidence to support the theory of the cistern. Finally, the opus caementicium platform, upon which the modern electrical tower stands, was found to have been extensively remodeled and further destroyed in modern times due to the creation of pipelines.

Although not completely conclusive, this academic research project, carried out by The American University of Rome, the Municipality of Giove, and Soprintendenza Archeologia, Belle Arti e Paesaggio dell'Umbria, has made it possible to contribute significant elements to the study of the archaeological landscape of the Tiber valley, an area of passage and intense cultural and social dynamism. This preliminary study provides a robust base upon which to proceed with further and more focused archaeological investigations in the area, with a possible dig in the near future (Figure 12). 

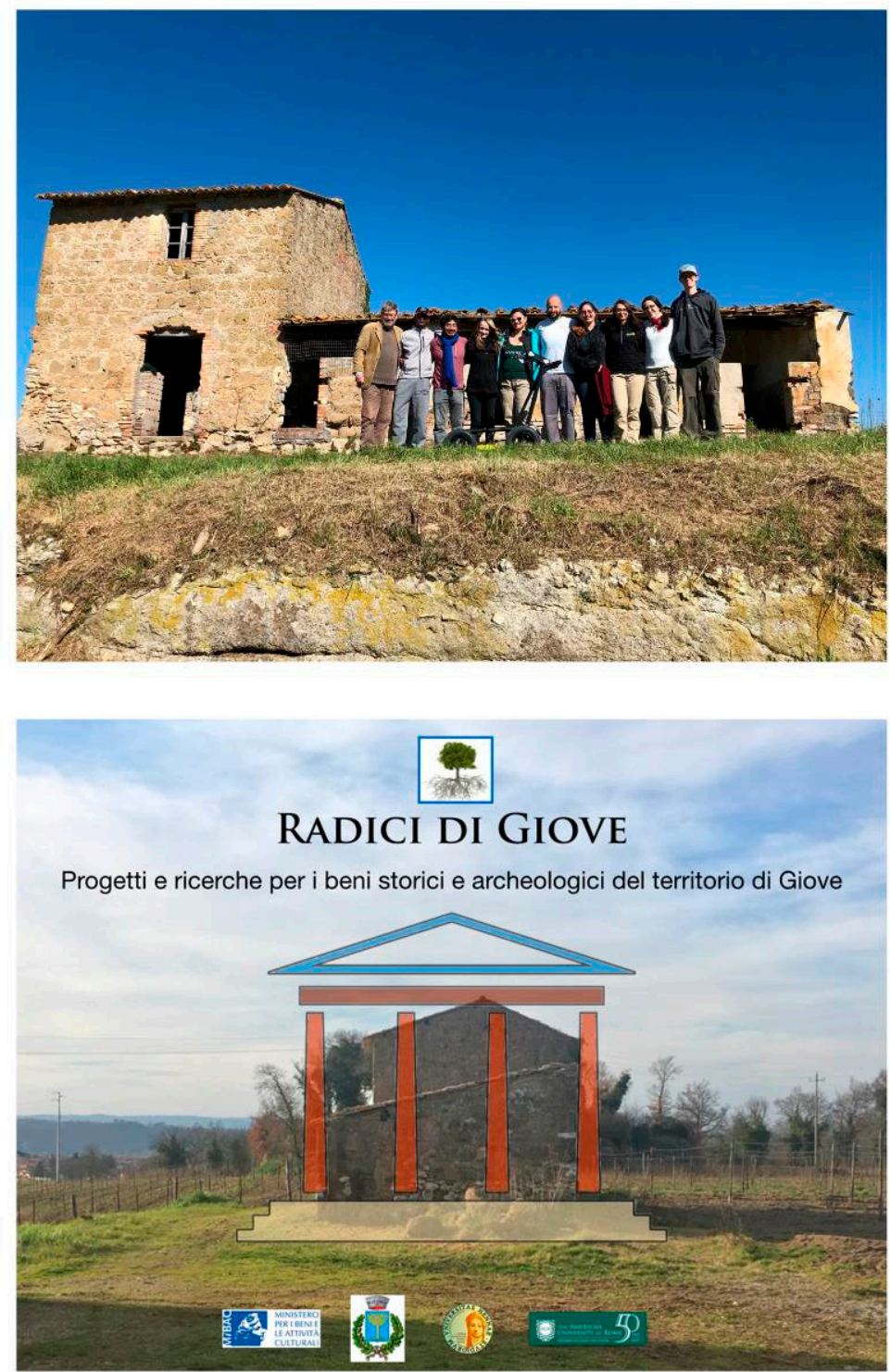

Figure 12. The academic team involved (above) and the research advertisement (below).

Author Contributions: Conceptualization, P.M.B., E.W., and R.H.; methodology, P.M.B., E.W., and R.H.; software, P.M.B., E.W., and R.H.; validation, P.M.B., E.W., and R.H.; formal analysis, P.M.B., E.W., and R.H.; investigation, P.M.B., E.W., and R.H.; resources, P.M.B., E.W., and R.H.; data curation, P.M.B., E.W., and R.H.; writing (original draft preparation), P.M.B., E.W., and R.H.; writing (review and editing), P.M.B., E.W., and R.H.; visualization, P.M.B., E.W., and R.H.; supervision, P.M.B., E.W., and R.H.; project administration, P.M.B., E.W., and R.H.; funding acquisition, P.M.B., E.W., and R.H. All authors have read and agreed to the published version of the manuscript. Funding: This research received no external funding.

Acknowledgments: The authors would like to thank Elena Roscini (Soprintendenza Archeologia, Belle Arti e Paesaggio dell'Umbria), arch., Alvaro Parca (Mayor of Giove), Sergio Fontana (SEMA snc), and the 7 AUR students involved in this project for their help, support, and passion.

Conflicts of Interest: The authors declare no conflicts of interest.

\section{References}

1. Alexakis, D.; Agapiou, A.; Hadjimitsis, D.; Sarris, A. Remote Sensing Applications in Archaeological Research; Intech: Oxford, UK, 2012; ISBN 978-953-51-0651-7. 
2. Campana, S. Remote sensing in archaeology. In Encyclopedia of Geoarchaeology; Gilbert, A.S., Ed.; Springer: Dordrecht, The Netherlands, 2017; pp. 703-725, ISBN 978-1-4020-4409-0.

3. Tapete, D. Remote Sensing and Geosciences for Archaeology; MDPI AG: Basel, Switzerland, 2018; ISBN 978-3-03842-763-6.

4. Parcak, S.H. GIS, Remote Sensing, and Landscape Archaeology. Available online: https://www. oxfordhandbooks.com/view/10.1093/oxfordhb/9780199935413.001.0001/oxfordhb-9780199935413-e-11 (accessed on 12 June 2020).

5. Guidi, G.; Frischer, B.; Russo, M.; Spinetti, A.; Carosso, L.; Micoli, L.L. Three-dimensional acquisition of large and detailed cultural heritage objects. Mach. Vis. Appl. 2006, 17, 349-360. [CrossRef]

6. Barone, P.M.; Maggio, R.M.D. Low-cost CSI using forensic GPR, 3D reconstruction, and GIS. J. Geogr. Inf. Syst. 2019, 11, 493-499. [CrossRef]

7. Campana, S. Drones in archaeology. State-of-the-art and future perspectives. Archaeol. Prospect. 2017, 24, 275-296. [CrossRef]

8. Conyers, L.B. Ground-penetrating radar. In Encyclopedia of Geoarchaeology; Gilbert, A.S., Ed.; Springer: Dordrecht, The Netherlands, 2017; pp. 367-378, ISBN 978-1-4020-4409-0.

9. Pajewski, L.; Persico, R.; Salucci, M.; Solla, M. Ground Penetrating Radar for archaeological investigations and cultural-heritage diagnostics: Research activities in the COST Action TU1208. 5. In Nondestructive Techniques for the Assessment of Historic Structures, Chapter: 13; CRC Press: Boca Raton, FL, USA, 2017; pp. $215-225$.

10. Trinks, I.; Hinterleitner, A.; Neubauer, W.; Wallner, M.; Gabler, M.; Filzwieser, R.; Wilding, J.; Schiel, H.; Jansa, V.; Schneidhofer, P.; et al. Large-area high-resolution ground-penetrating radar measurements for archaeological prospection. Archaeol. Prospect. 2018. [CrossRef]

11. Persico, R. Introduction to Ground Penetrating Radar: Inverse Scattering and Data Processing; New edizione; IEEE: Hoboken, NJ, USA, 2014; ISBN 978-1-118-30500-3.

12. Barone, P.M. Understanding Buried Anomalies: A Practical Guide to GPR; LAP LAMBERT Academic Publishing: Saarbrücken, Germany, 2016; ISBN 978-3-659-93579-4.

13. David, B.; Thomas, J. Handbook of Landscape Archaeology; Routledge: Boca Raton, FL, USA, 2016; ISBN 978-1-315-42771-3.

14. Greene, K. Archaeology of the Roman Economy; Univ of California Press: Berkeley, CA, USA, 1992; ISBN 978-0-520-07401-9.

15. Dyson, S.L. The Roman Countryside; Bristol Classical Press: London, UK, 2003; ISBN 978-0-7156-3225-3.

16. Mancini, M.; Girotti, O.; Cavinato, G.P. Il Pliocene E Il Quaternario Della Media Valle Del Tevere (Appennino Centrale). Geol. Romana 2004, 37, 64.

17. Patterson, H. Bridging The Tiber: Approaches To Regional Archaeology In The Middle Tiber Valley; British School at Rome: London, UK, 2004; ISBN 978-0-904152-40-1.

18. Gasperoni, T.; Scardozzi, G. Bomarzo, Mugnano, Bassano in Teverina: I.G.M. F137 I SO Attigliano, II NO Soriano nel Cimino; Carta Archeologica d'Italia ed.: Viterbo, Italy, 2010.

19. Witcher, R. Broken pots and meaningless dots? Surveying the rural landscapes of Roman Italy. Pap. Br. Sch. Rome 2006, 74, 39-72. [CrossRef]

20. Scardozzi, G. Carte archeologiche nella Provincia di Viterbo: tra conoscenza e conservazione. In Proceedings of the Multi-, Inter- and Transdisciplinary Research in Landscape Archaeology; VU E-Publishing: Amsterdam, The Netherlands, 2016.

21. Interpretare i bolli laterizi di Roma e della valle del Tevere: produzione, storia economica e topografica - Vol. 32 Acta Instituti Romani Finlandiae-Arbor Sapientiae Editore S.r.l. Available online: https://www.arborsapientiae.com/libro/3983/interpretare-i-bolli-laterizi-di-roma-e-della-valle-del-tevereproduzione-storia-economica-e-topografica-vol-32-acta-instituti-romani-finlandiae.html (accessed on 13 May 2020).

22. Gasperoni, T. Le Fornaci dei Domitii: Ricerche Topografiche a Mugnano in Teverina; Daidalos, Ed.; Università della Tuscia: Viterbo, Italy, 2003.

23. Johnson, P.; Keay, S.; Millett, M. Lesser urban sites in the Tiber Valley: Baccanae, Forum Cassii and Castellum Amerinum. Pap. Br. Sch. Rome 2004, 72, 69-99. [CrossRef]

24. Gasperoni, T. Mugnano in Teverina, località Rota Rio. Recenti indagini su fornaci di opus doliare: relazione preliminare. In Daidalos: Studi e Ricerche del Dipartimento di Scienze del Mondo Antico, 10.2010; Università della Tuscia: Viterbo, Italy, 2010; pp. 175-185. 
25. Aureli, P.; Brolli, M.A.D.L.; Lungo, S.D. Soprintendenza per i Beni Archeologici dell'Etruria Meridionale. Orte (Viterbo) e il suo territorio: scavi e ricerche in Etruria meridionale fra antichità e Medioevo; John and Erica Hedges Ltd.: Oxford, UK, 2006; ISBN 978-1-84171-758-6.

26. Shepherd, E.J.; Capecchi, G.; de Marinis, G.; Mosca, F.; Patera, A. Rassegna di Archeologia, 22/B, 2006-Classica e Postclassica-Le Fornaci del VINGONE a SCANDICCI. Un Impianto Produttivo di età Romana Nella Valle dell'Arno; All'Insegna del Giglio: Firenze, Italy, 2008; ISBN 978-88-7814-356-2.

27. Gasperoni, T. Un nuovo insediamento produttivo di opus doliare nella media valle del Tevere. In Territorio e Produzioni Ceramiche. Paessagi, Economia e Società in età Romana. Atti del Convegno Internazionale, Pisa, Ottobre 2005. Territory and Pottery. Landscapes, Economy and Society in Roman Times. Proceedings of the International Meeting, Pisa, ottobre, 2005; Edizioni Plus: Pisa, Italy, 2006; pp. 113-128.

28. Gasperoni, T. Uno scalo ed un attraversamento del Tevere; Daidalos, Ed.; Università della Tuscia: Viterbo, Italy, 2012; pp. 245-255.

29. Paglialunga, L. Orte Preromana Romana E Del Primo Medio Evo; Menna: Avellino, Italy, 1963.

30. Scortecci, D. La Media e Alta Valle del Tevere Dall'antichità al Medioevo: atti della Giornata di Studio (Umbertide, 26 maggio 2012); Daidalos, Ed.; Università della Tuscia: Viterbo, Italy, 2014; ISBN 978-88-908454-0-6.

31. Le carte del Lazio-Amato Pietro Frutaz-Google Libri. Available online: https://books.google.it/books/ about/Le_carte_del_Lazio.html?id=WWYZnQAACAAJ\&redir_esc=y (accessed on 19 May 2020).

32. De Catino, G.; Balzani, U. Il Chronicon Farfense di Gregorio di Catino; Forgotten Books: London, UK, 1972; ISBN 978-5-88415-399-8.

33. Cimarelli, C.; De Rita, D. Structural evolution of the Pleistocene Cimini trachytic volcanic complex (Central Italy). Bull. Volcanol. 2006, 68, 538-548. [CrossRef]

34. Nibby, A. Analisi Storico-Topografico-Antiquaria della Carta de' Dintorni di Roma; Tip. delle Belle arti: Rome, Italy, 1849.

35. 3DF Zephyr Manual 4.500 English.pdf. Available online: http://3dflow.net/zephyr-doc/3DF\%20Zephyr\% 20Manual\%202500\%20English.pdf (accessed on 13 May 2020).

36. Menduini, E. L'Autostrada del Sole; Il Mulino: Bologna, Italy, 1999.

37. AA.VV. Storia dell'Ingegneria-Atti del $1^{\circ}$ Congresso Nazionale; Cuzzolin Editore: Napoli, Italy, 2006.

38. Barone, P.M. Bombed archaeology: Towards a precise identification and a safe management of WWII's dangerous unexploded bombs. Heritage 2019, 2, 2704-2711. [CrossRef]

(C) 2020 by the authors. Licensee MDPI, Basel, Switzerland. This article is an open access article distributed under the terms and conditions of the Creative Commons Attribution (CC BY) license (http://creativecommons.org/licenses/by/4.0/). 